Buddhist Law in Burma 



\section{Buddhist Law in Burma}

A HISTORY OF DHAMMASATTHA TEXTS

AND JURISPRUDENCE, 1250-1850

D. Christian Lammerts

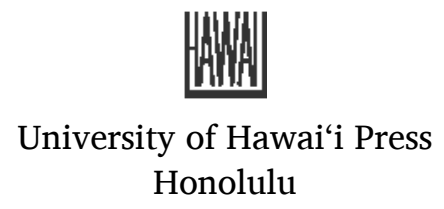


(C) 2018 University of Hawai'i Press

All rights reserved

Printed in the United States of America

2221201918

$6 \begin{array}{llllll}6 & 4 & 3 & 2 & 1\end{array}$

\section{Library of Congress Cataloging-in-Publication Data}

Names: Lammerts, Dietrich Christian, author.

Title: Buddhist law in Burma : a history of dhammasattha texts and jurisprudence, 1250-1850 / D. Christian Lammerts.

Description: Honolulu : University of Hawai'i Press, [2018] | Includes bibliographical references and index.

Identifiers: LCCN 2018019170 | ISBN 9780824872601 (cloth ; alk. paper)

Subjects: LCSH: Burmese Buddhist law-Sources. | Law-Burma-Buddhist Influences-History-Sources.

Classification: LCC KNL133 .L36 2018 | DDC 349.59109/03dc23

LC record available at https://lccn.loc.gov/2018019170

Cover art: (front) Painted mural register depicting the legal judgment of the bodhisatta Candakumāra in the Khandahāla jātaka. Zeditaw temple complex, Aneint, late eighteenth century (photograph by Than Zaw).

Detail of manuscript folios of the Manusāradhammasattha and Manu ranh nissaya dhammasat (NL Tan $10 \mathrm{f}$. gū recto and UCL $8000 \mathrm{f}$. jau verso, respectively). (back) Terracotta plaque depicting the bodhisatta as the boar-king and judge Mahātuṇdila in the Tundila jātaka.

East Hpetleik temple, Pagan, eleventh century (photograph by Than Zaw).

University of Hawai'i Press books are printed on acid-free paper and meet the guidelines for permanence and durability of the Council on Library Resources. 
For Chie 
